\title{
Középiskolások okostelefon-használati szokásai 2015-ben
}

Empirikus kvalitatív kutatásunk célja a középiskolások okostelefon-használati szokásainak, gyakorlatainak feltárása, az ezzel kapcsolatos vélemények, attitüdök, élmények megismerése és bemutatása. Kutatási jelentésünkben részletesen leírjuk és elemezzük a ma 15-19 éves korosztály első okostelefonnal kapcsolatos emlékeit és élményeit, a telefoncserék okát, amely egy-két, ritkán három évente megtörténik. Itt az újdonság erejét, a kortárs csoport elvárását, illetve az állandó jelenlétet, a folyamatos kommunikáció biztosítását, a gyors/azonnali továbbítás lehetőségét emeljük ki. Beszámolónkban részletesen kitérünk a telefon-alkalmazásokra, azok használatára, illetve nem-használatára, valamint a márkahűségre. A diákok okostelefonjuk mellett napi szinten használnak laptopot, tabletet vagy asztali számítógépet, de mindegyik készüléket más feladatokra veszik igénybe. A szülők elvárásait és preferenciáit is érintjük. Kutatásunk azt mutatja, hogy a mai középiskolások nem tudják elképzelni az életüket okostelefon nélkül, de ha sikerül mással lekötni a figyelmüket, sokkal kevesebbet használják, sőt egy érdekes és izgalmas program esetén (például nyaralás, házibuli) nem hiányzik nekik az online jelenlét és a többiekkel való állandó kommunikáció.

Kulcsszavak: kvalitatív kutatás, ifjúságkutatás, középiskolások, okostelefon, okostelefon-használat

\section{Szerzői információ:}

Sólyom Barbara szociológus, kutató, az Óbudai Egyetemen az Egyetemi Kutató és Innovációs Központban múködó Digitális Kultúra és Humán Technológiai Tùdásközpont tudományos munkatársa, korábban az Információs Társadalom- és Trendkutató Központ kutatója. Az ELTE BTK Szociológia Intézetében végzett szociológusként (2002), doktori fokozatát a Budapesti Corvinus Egyetemen szerezte (2015). Angol és magyar nyelvú cikkei, tanulmányai olvashatóak etnikumok közötti kapcsolatokról (pl. KOME, Jel-Kép, Tabula, Kultúra és Közösség, MTA Kisebbségkutató Intézet), illetve különbözố empirikus kutatásokról (pl. Információs Társadalom). Tudományos tevékenysége mellet rendszeresen végez piackutatásokat is, a legkülönbözóbb témákban.

Így hivatkozzon erre a cikkre:

Sólyom Barbara. „Középiskolások okostelefon-használati szokásai 2015-ben”.

Információs Társadalom XV, 2. szám (2015): 55-68.

$=$ https://dx.doi.org/10.22503/inftars.XV.2015.2.4

A folyóiratban közölt müvek

a Creative Commons Nevezd meg! - Ne add el! - Így add tovább! 4.0

Nemzetközi Licenc feltételeinek megfelelően használhatók. 


\section{Sólyom Barbara}

\section{Középiskolások okostelefon-használati szokásai 2015-ben}

\section{Bevezetés}

Az Óbudai Egyetem Digitális Kultúra és Humán Technológia Tưdásközpontjának célja az információs társadalom szerteágazó jelenségeinek vizsgálata. Kiemelten foglalkozunk az ifjúság és a digitális kultúra viszonyának témakörével. 2015-ben a Nemzeti Média- és Hírközlési Hatóság támogatásával egy olyan alapkutatási programot indítottunk el, mely segíti az ifjúság és a digitális kultúra viszonyának holisztikus és hosszú távú, empirikus megértését. A hosszabb távú kutatás eredményei egyaránt szólnak az állami szférának, a jogalkotóknak, a tanároknak és a szülóknek.

Az okostelefon az információs társadalom infokommunikációs eszköztárának talán legfontosabb eszköze testreszabottsága és állandó jelenléte miatt. Az okostelefon-jelenség mélyebb megértése érdekében kvalitatív kutatást indítottunk, hogy emberi érzelmeket, élményeket, emlékeket, attitúdöket, gondolatokat és véleményeket tárjunk fel, és ezzel a tudással egészítsük ki a - más kutatások eredményeképpen - már meglévô, jellemzóen kvantitatív adatokat.

Ezt a primer kutatást terveink szerint több célcsoportban is elvégezzük. Jelen beszámolónkban az általunk eddig vizsgált egyetlen csoport, a 15-19 éves magyar középiskolások körében végzett kutatás eredményeit közöljük. A jövóben az okostelefon-használat szokásainak átfogó feltárásához azonban szükségesnek tartjuk más korosztály, illetve más élethelyzetben lévốk megkérdezését is. A továbbiakban ezért interjúkat készítünk majd a fiatalabb korosztállyal is (általános iskolás felsố tagozatosok, 10-14 évesek), a felsốoktatásban részvevókkel (nappali tagozatos egyetemisták és fóiskolások, 19-25 évesek), valamint az ebbe a korosztályba tartozó nem tanulókkal, a dolgozókkal. Természetesen érdemes vizsgálódnunk, és nagy valószínúséggel más eredményeket kapunk a harmincasok, negyvenesek és már családdal rendelkezók körében, valamint az idôsek - aktívak és inaktívak - körében is. A téma kutatásakor az életkori megoszlást tarjuk szem elôtt, tudva, de nem számolva számos más tényezóvel, változóval.

\section{A kutatás célja}

Kutatásunk célja az okostelefon-használat szokásainak, gyakorlatainak feltárása, a használatával kapcsolatos vélemények, attitûdök, élmények megismerése és bemutatása. A téma nagyon aktuális, ezt támasztják alá a legfrissebb kvantitatív kutatások is. Az Ithaka Research Consulting 2015-ös felmérése szerint ${ }^{1}$ a vizsgált korosztályban (2464 foót kérdeztek

\footnotetext{
${ }^{1}$ A kutatás eredményei még feldolgozás alatt állnak. Az itt szerepló adatok Ságvári Bence: Élet az eszközökben, avagy van-e új a nap alatt címú konferencia elôadásából származnak (Nemzetközi Gyermekmentő Szolgálat - VIII. Nemzetközi Médiakonferencia, Balatonalmádi, 2015. szeptember 29.)
} 
meg) 90-95 százalékos a saját okostelefonnal rendelkezók aránya. 2015-re lényegében befejezốdött a fiatalok „okostelefonizációja”, vagyis kevés kivétellel mindenkinek van már legalább egy készüléke. A fiatalok 68 százaléka mobilinternettel is rendelkezik, így okostelefonjaikon keresztül - eltéró mértékben és lehetôséggel ugyan, de - folyamatosan online állapotban vannak. Ahogy a kutatás is kiemeli: az offline és az online határai gyakorlatilag eltúntek.

A mélyinterjúkat a legelsố okostelefonnal kapcsolatos emlékekkel, élményekkel kezdtük. Ezután a következô okostelefon kiválasztásáról, annak szempontjairól, lecserélésének okairól kérdeztük alanyainkat. Az okostelefonok alkalmazásának tárgykörét részletesebben körüljártuk, hiszen tudni szerettük volna, mire vagy mire nem, mikor és hogyan használják, illetve mire szeretnék még használni azokat. Van-e más infokommunikációs eszközük telefonjukon kívül, illetve ezek közül mit, mire használnak? Mennyire elégedettek telefonjukkal, mikor és milyen szituációkban voltak bosszúsak a készülék miatt, valamint az okozott-e nekik meglepetést, örömöt? Szerettük volna megismerni a szülók szerepét a telefon kiválasztásában, fenntartásában, használatában, emellett megtudni azt, hogy milyen szülói kontroll alatt tartják a diákokat, és milyen elvárásoknak kell megfelelniük telefonhasználatukkal kapcsolatban. Interjúalanyaink okostelefon-használati szokásait, a külsôségek fontosságát összekapcsoltuk a személyes identitás témakörével. Vajon mennyire játszik szerepet telefonjuk az énkép felépítésben, megtartásában? Végül befejezésként megkérdeztük, hogy tudnának-e élni okostelefon nélkül, és ha igen, ez hogyan változná meg mindennapjaikat? És ha elófordult már velük, hogy nélkülözniük kellett (pl. elveszett, ellopták vagy tönkrement a telefon), azt hogyan élték meg?

\section{A kutatás módszertana}

Mivel kutatásunkban véleményekre, attitúdökre, érzésekre és élményekre voltunk kíváncsiak, a kvalitatív társadalomtudományi kutatási módszerek közül alkalmaztunk kettót: a mélyinterjút és a storytelling módszerét, egyidejúleg. Kvantitatív, kérdôíves felmérést nem végeztünk, ugyanis tapasztalataink szerint már számos hazai és nemzetközi kutatás készült ezzel a módszerrel, és valószínúleg még fog is, hiszen több kutatócsoport longitudinális vizsgálatokban gondolkodik. Azonban a kérdőíves lekérdezések adataiból nem tudunk meg sok olyan információt, amelyek fontosak a téma részletes bemutatása szempontjából. Ilyenek az általunk feltárt érzelmi összetevók és ezek megnyilvánulása.

Kutatásunkban 10 középiskolást, 15 és 19 év közöttieket kérdeztünk meg, közülük 7 fő gimnazista, 3 fó szakközépiskolás, 6 fiú és 4 lány volt. Lakhelyük és iskoláik Budapesten, illetve a Pest-megyei agglomerációban található. Törekedtünk arra, hogy iskoláik oktatási színvonalukat tekintve eltéróek legyenek, illetve arra, hogy interjúalanyaink családi háttere különbözó legyen. Fontos szempont volt, hogy a szülók végzettsége és foglalkozása változatos legyen. A szülói mintába végül a következó foglalkozások kerültek: kéményseprô, asztalos, felszolgáló, múszerész, könyvelő, adminisztrátor, gyógyszergyári laboráns, gyógyszerész menedzser, gazdasági szférában középvezetô, tanító, egyetemi tanár, gyógypedagógus, bíró. A családi összetétel és a lakókörnyezet szintén különbözött. 


\section{Kutatási eredmények}

\section{Az elsó okostelefon}

Az elsố okostelefonokat interjúalanyaink négy-öt éve kapták, illetve szüleiktól kérték, amikor az általános iskola hetedik-nyolcadik osztályába jártak. Ekkortól kezdtek el önállóan utazni, szórakozni járni a barátokkal, randevúzgatni. Vagyis innentól kezdve vált intenzívebbé a társasági élet, melynek hatására a szülók lényegesnek tartották egy telefon beszerzését, amellyel szükség esetén bármikor elérhetik gyermeküket.

Fontos szempont volt az újdonság (például az érintóképernyő sokaknak tetszett), a „menózés” ereje, amellyel környezetükben elismerést válthattak ki. Azokban az években (2011-2012-ben) kezdtek elterjedni az okostelefonok, amelyre a legtöbb gyerek szert akart tenni.

Akkor még nem pontosan tudták, milyen funkciói vehetók igénybe, elsôsorban játékra és a barátokkal való kommunikációra (fóleg a Facebookra), valamint zenehallgatásra (útközben és az iskolában is) használták, néhányan adott esetben a számológépet vették még rajta igénybe. Nagyon ritkán telefonáltak vele (akkor is inkább a szülóket hívták), és még ritkábban SMS-eztek. Levelezést (e-mail) egyáltalán nem folytattak. Híreket, érdekességeket (böngészés) még nem olvastak ekkoriban. Zenéket töltöttek rá, szelfiket készítettek vele. Volt, akinél a mobilinternet sem múködött még, de ez nem zavarta, otthon böngészett a világhálón. Akkor még nem volt lényeges szempont, hogy az okostelefonon mobilinternet is múködjön, de egyre erósödött ez az igény is, hiszen három-négy éve már sok korosztálybeli Facebookon kommunikált, és akinek nem volt okostelefonja, az lemaradhatott valamilyen fontos információról vagy eseményról, amelyról a csoportjában beszéltek.

A fiatalabb testvérek örökölték a nagyobbak telefonjait, ezek egy-másfél éves, még múködóképes darabok voltak, amelyek általában lassabban múködtek, mint az új típusúak. Az idôsebb testvérek könnyen adtak túl rajtuk, hiszen újat vásároltak helyette. Az egygyermekes családokban a korábbi, hagyományos mobiltelefonok meghibásodása, használhatatlansága miatt került sor a cserére (nem múködtek a gombok, magától kikapcsolt, vagy egyáltalán nem kapcsolt be a telefon). A hagyományos készülékeket érintốképernyốs telefonok, okostelefonok váltották föl.

„...akkor ast mondtam apának, olyan érintóképernyóst kérek, amin lehet normálisan játszani, és van rajta Facebook. Nekem csak ez kellett még akkor, és így lett. Lényeg, hogy múködjön."

Az első okostelefon vásárlása fóként szülói segítséggel történt. A gyerek általában az apukájával választotta ki az interneten mit szeretne, miután összehasonlították a különbözó készülékeket ár és dizájn alapján. Négy-öt éve a szülók jobban eligazodtak a telefonok piacán, mint ma, akkor még akkora erejú újdonságnak számított az okostelefon, amely az ó érdeklődésüket is felkeltette. Mára ez megváltozott, a szülók többsége nincs tisztában a telefonok paramétereivel, nem tudja, mi alapján kellene választania gyerekének, az infokommunikációs eszközök piacának gyors változását nehezen vagy egyáltalán nem képesek követni. Ahogy egyik alanyunk mondta:

„Ááá, dehogy...teljesen elvesztették a fonalat. De nem csodálom. Az elsót még együtt néztük ki, ma már egy szót sem ért abból, amit mondok, próbálom elmagyarázni neki, de látom rajta, hogy nem mindig érti. Néha visszakérdez, vagy újra megkérdezi, ez meg ez mit jelent, vagy mi az rajta, igyekswik, de valamikor csak legyint, és hagyja." 
Az elsố telefonok múködését a megkérdezett diákok jelentôs többsége egymaga tanulta meg kezelni, nézegette, próbálgatta az alkalmazásokat és az eszközöket, illetve barátaikkal, osztálytársaikkal együtt fedezték fel a lehetôségeket. A kevésbé népszerú és ismert alkalmazásokat csak ritkán próbálták ki, fóként azokat használták, amelyeket a többiek is. Az árak, tarifák és számlák világát is ekkor ismerték meg, ekkortól kezdtek el figyelni „fogyasztásukra”. Néhány fő az interneten nézett utána a tudnivalóknak és/vagy elolvasta a használati utasítást. Az egyik 16 éves szakközépiskolás lány például nem tudta, hogyan kell a képernyốt lementeni (a képernyớról való képkészítésról van szó), de interneten utánanézett, amikor a háttérátállítással sem boldogult, elôvette a kezelési útmutatót.

A megkérdezett 10 fiatal jelenleg a harmadik-ötödik telefonját használja, és ez négy-öt éves idôtartamot fed le.

\section{Lecserélés, újabb okostelefonok}

A telefonokat szinte minden esetben egy-másfél, maximum kétévente cserélik le, és nem elsôsorban meghibásodás vagy használhatatlanná válás miatt, hanem mert egyrészt vonzódnak az újhoz, másrészt az elvárásoknak eleget téve követik társaik példáját. Nem is törekednek arra, hogy olyan telefont vásároljanak, amely három évnél tovább megfelelóen múködik - többen határozottan úgy vélik, hogy a mai készülékeket eleve két-három évre tervezik. Elfogadják ezt a helyzetet, sốt igénylik az újat és a jobbat még úgy is, hogy tisztában vannak vele: nagy változások és jelentôs különbségek ma már nincsenek az egyes telefonok között.

„Miután megkaptam, mindig egy-két és fél év után jöttek a problémák, lelassult. Valamiért úgy vannak ezek gyártva, hogy kétévente lecserélje az ember, fóleg az alsó szériások. Ekkor kinézem már a következót. Az idót lehet hú:ni asaal, hogy gyakran kikapcsolgatja az ember, vagy a futó alkalmazásokat kilövi, meg minél kevesebb alkalmazást tölt le, hogy ne terhelje a késziiléket, de igy is egyre lassabb lesz. Na, ez a korsæak idegtépó tud lenni."

„Olyan telefon, ami valami miatt tönkrement és azért cseréltem volna le, olyan nem is volt... eleinte a: új dizájn volt a: oka, utána már a belsó is érdekelt szerintem, hogy mivel jobb, meg ilyenek, de igen, nálam, ha telefont válasstok, akkor számít a disájn is, ezek a külsó dolgok. Egy számítógépnél nem érdekelne annyira, ott tényleg a belsố a fontos, de itt igen."

„Az iPhone 5 vagy $5 S$ között vacilláltam, de igazából annyira nem lehet óket összehasonlitani, mert ugyanast tudja mindegyik telefon, a kamerájuk, a képernyófelbontása egyiknek sem jobb, ugyanolyan hangos, ugyanazt tudod vele csinálni, csak az 5S-ben ujjlenyomat-olvasó van. Ez volt fontos, aะ nagyon tetszett, azért kértem."

Minden megkérdezett diák a lelassulás, lefagyás, sốt többen a hirtelen magától kikapcsolás vagy bekapcsolás, a nehéz és többszöri újraindítás miatt cserélte le a telefonját. De sokszor elég, ha a készülék kicsit lassabb vagy egyszer lefagy ahhoz, hogy új készülék után nézzenek.

Ketten a készülék gyors felmelegedésére panaszkodtak, ilyenkor állítólag annyira képes felforrósodni, hogy alig lehet hozzáérni.

Két-három éve már minden alanyunknál nélkülözhetetlen a mobilinternet, melyre az állandó kommunikáció miatt van szükség. Az elsớdleges szempont egy telefoncserénél a gyors és állandó jelenlét, valamint a gyors/azonnali továbbítás. 
Új telefon vásárlásánál szempont a teljesítmény és a termék dizájnja, szépsége. A megkérdezettek válaszaiból az derül ki, hogy a szempontok sorrendje változó. A többség az elsố helyek egyikére teszi a teljesítményt („tudod, hogy mennyit bír gigában meg akksiban”), a memóriát, a processzort, a kijelzó méretét, a kamerát és csak utolsó helyre a dizájnt. De volt két-három alanyunk is, akiknél a telefon külseje a legfontosabb tényezók között szerepelt.

„A belső is fontos, de a külsó is sokat számít, mert sokat dob a telefonon.”

„Hát az elsó a külsó, amit nézek, az a legfontosabb, utána jöhet a többi dolog."

A megkérdezett diákok tudatosan vásárolnak, mérlegelnek, hogy mire használnák a kiszemelt készüléket, ehhez képest rangsorolják elvárásaikat is. Barátoktól, ismerôsöktól és az internetról szedik információikat a telefonokról. Az iPhone használók kiemelték, hogy az iPhone minden évben kitesz egy tíz perces kisvideót legújabb készülékéról, amiben mindent elmondanak és bemutatnak az új típusról. Ezek a kisfilmek nagyon informatívak, így mindig megnézik óket, és csak utána döntenek arról, kell-e nekik az új típus vagy sem.

„Ast mérlegeltem, hogy nekem mi éri meg, mennyit nyomkodom, mire hasะnálnám, és ezekhez mérten választottam. Nekem negyven-negyvenötezer forintnál drágább készülék nem igazán kell, mert nem használom ki, nem nyomkodom annyit. ...Anyám is mondta, hogy nem az ár számit, hanem hát úgy mérlegeljek, hogy mennyire kell nekem, mennyit ér meg. Tehát nekem a száz-valamennyi, a szá: fölötti mobil nekem nem éri meg, nem szïkséges. Mondjuk, úgysem tudnánk megvenni, maximum beleadok, vagy tovább dolgozom, és késóbb veszem meg."

„Egy nagyon drága, mondjuk,kétszáz-háromszázezres telefon nem tudna annyival többet, hogy kiadjon érte az ember ennyit. Ugyanúgy Skype-ra, Face-re, Instagramra és Snapchatre használnám, legfeljebb ezek gyorsabban történnének, és több hely lenne rajta a fényképeknek, de annyival nem érne többet."

A telefonok cseréje mindenkinél egy nagyobb ünnepre, különleges alkalomra esik születésnapra vagy karácsonyra, hiszen ilyenkor a család nagyobb összeget hajlandó kiadni egy ajándékért, még ha a szüloók a legkedvezóbb feltételekkel is igyekeznek vásárolni, például gyứjtốpontokat használnak fel, vagy kezdőrészletre vásárolnak. A pontokért való vásárlás ugyan leszúkíti a választékot, de a megkérdezettek szerint még ilyenkor is bố a felhozatal. Amíg a diákok meg nem kapják az új telefont, addig vagy a régebbit használják, vagy ha az már nem múködik megfelelóen, esetleg már nincs a birtokukban egy korábbi, akkor az otthoni, ,vésztartalékban” tartott telefont.

\section{Okostelefon-használat}

Mindenkinél, kivétel nélkül, az állandó kommunikáció, a „fennlevés” az elsôdleges szempont. A megkérdezettek napi szinten, állandóan használják a Facebookot, Messengert, Snapchatet, Instagramot, WhatsAppot, Vibert. A Skype-ot is említhetnék, de mivel a feleknek szinkronban kell lenniük, vagyis azonos idóben kell az internetes elérhetôséget biztosítaniuk - illetve az intim körülmények megteremtése is szükséges hozzá -, csak ritkán veszik igénybe. Zenehallgatásra szintén mindenki használja, régebben letöltötték a számokat, de ma már vannak ingyenes alkalmazások is, mint például a Spotify.

Rendszeresen fotóznak. Aki komolyabban foglalkozik képkészítéssel, és szerkeszteni is szeretné azokat, az képszerkesztói alkalmazást (Pixart) is letölt telefonjára. Elsố okoste- 
lefonjuknál a fotózás még nem volt olyan mindennapos, mint mostanában, mert akkor a telefonok még nem tudtak olyan minôségú képet készíteni, mint szerették volna.

Kisebb videókat, klipeket is szoktak nézni a telefonjukon.

Az interneten való böngészés, a hírek olvasása korral változik: minél idôsebb az alany, annál gyakoribb, és annál inkább fontosnak tartja ezeket. A 15-16 évesek csak azokat a híreket vagy érdekességeket olvassák, amiket a Facebookon küldenek nekik. Ha a tanuláshoz rövid információkra van szükségük, megkeresik a telefonjukon keresztül (például szótár, Wikipédia szócikkek), de a komolyabb és terjedelmesebb, összetett feladatok megoldását inkább laptopon, tableten vagy asztali gépen végzik.

Telefonálni nagyon ritkán szoktak, SMS-t is csak alkalomadtán küldenek, mindent interneten próbálnak elintézni, mert az olcsóbb (wifi esetében ingyenes). Elsôsorban a wifi-használatra törekednek, ennek hiányában rendelkezésre áll a mobilinternet.

„És egyébként sincs értelme telefonálgatni a barátoknak, mert mindig mindenki fenn van a neten. Így legalább többen is tudunk egyszerre beszélni, meg a telefonálás olyan elavult már. Csak anyáékkal ssoktam, de ók meg nincsenek Face-en, illetve anya szokott néha, apának nincs is."

A megkérdezett fiatalok közül többen említették még a leggyakrabban használt alkalmazások között az útvonaltervezést, a térképet, a zenefelismerő programot (Shazam), a Budapest menetrendet, az idôjárás eloorejelzést, az ébresztô órát, a mozimúsort, a naptárt, fordító programokat. Fényképeket és tanulnivalókat, jegyzeteket, könyvfejezeteket e-mailen keresztül szoktak egymásnak küldeni, egyszerú kezelhetôsége miatt a tanárokkal való kapcsolattartás is e-mailben történik.

Egyéb applikációk, amiket használnak: videotelefon (Face'Time); zeneletöltés (Podcast); a FindMyFriends alkalmazás a fesztiválok ideje alatt nagyon hasznosnak bizonyult, és azóta is használják; egyes ruhaboltok alkalmazásai (H\&M, Pull\&Bear); Netpincér; AppStore; Számológép; Nike+Running; GoPro program alkalmazása; továbbá a szolgáltató alkalmazása is fontos (pl. Vodafone); OTP SmartBank; BarcodeScanner.

A telefonra telepíthetô játékok nagy tárhelyet foglalnak, ezért az internetes játékokat részesítik elônyben, amelyekkel a barátok akár együtt is játszhatnak (gombfocis játék, PixWords, logikai játékok), Druskate, busz szimulátor, billiárd, bugyuta játékok unalomúzésként (FlappyBird), autós játékok, arcade játékok, Plague, AngryBirds, Star Wars. Az elmondások szerint, ha már tíz percet várni kell egy játék betöltốdésére, akkor inkább keresnek helyette egy másikat.

A diákok az iskolában gyakran órán és vizsgák alatt is használják a telefont, sokan puskáznak belóle, vagy a Facebookon kérnek segítséget társaiktól.

Kutatásunkban rákérdeztünk arra, hogy ha alanyaink megvesznek egy új készüléket, az elsố bekapcsolás után mi az elsố lépésük, mit állítanak be elôször. Kivétel nélkül a mobilinternet bekapcsolását, a Facebook, a Messenger, a WhatsAp, a Snapchat és az Instagram letöltését tartották a legfontosabbnak. Ezt követôen rendezgetik a már meglévố állományukat, az alkalmazásokat, a programokat és a különbözó tartalmakat. Ilyenkor a legtöbbször ugyanoda tesznek mindent, ahol az előzó telefonjukon is volt, ahogy eddig megszokták, így továbbra is minden kézre esik. Utána követkehet a háttérkép beállítása. A csengóhang már nem érdekli óket annyira, mint néhány éve, ugyanis nem használják, szinte mindenkinek rezgó állapotúra van állítva telefonja, hogy senkit ne zavarjon a csengetés. Korábban gyakori volt - még az elsố okostelefonjuk idejében - az aktuális kedvenc zeneszám alkalmazása csengóhangként, de ma már kevésbé érdekli óket ez a lehetôség, és bonyolult a 
beállítása is. A háttérképekkel nemigen foglalkoznak, mert nem látszódnak, annyi ikont tesznek ki a kezdő oldalra/asztalra, hogy teljesen eltakarják a hátteret.

Fontos, hogy a megszokott telefonmárkát vegyék. Nagyon ritkán váltanak, mert nem szívesen tanulnák meg egy új rendszer kezelését. Aki egyszer iPhone-t kapott, ragaszkodik az iPhone-hoz, mert az androidos telefonok más elvek alapján múködnek és nehéz áttenni a meglévố applikációkat és tartalmat egy másik készükére, egy másik rendszerbe. (Igaz, az iPhone korlátolt lehetóségekkel rendelkezik.) Természetesen a fordítottja is igaz, aki eddig androidos telefont használt, nem mer iPhone-t kérni, mert nem ismeri eléggé, és a már megszokott márka biztonságot jelent a számára.

„Azért iPhone, mert a nóvéremnek is az volt, onnan ismertem, rögtön olyat kértem én is, de egy újabb változatot. Nem is gondolkodtam más márkában, ezt megszoktam, tudom, mit hogyan kell rajta... nem tudnék mást elképzelni, teljesen más a rendszere, mint a többinek, nekem egyszerübb és letisztultabb, mint a többi, sæép a külseje is, könnyü használni, csak ilyet veszek. Próbáltam mást is, Blackberryt, meg kölcsönkaptam egy Samsungot, de nem jött be, nem szerettem óket, bénáztam veliik. Mondjuk húzós az iPhone ára, de én csak azt akarom, inkább megdolgozok érte... egy suliszövetkezetben szoktam munkát vállalni, nyáron is meg suli mellett is, három év alatt összejön annyi, hogy vegyek egy újabb iPhone-t. Már most gyüjtök a következóre, pedig ez még új, csak másfél-két éves... karácsonyra szeretném, anyuék is beleadnak, általában fele-fele arányban jön ki, és mindig részletre vesszük. Én ebben bizom, ezt ismerem, ebbe nóttem bele."

Számos olyan alkalmazás van egy telefonon, amit sosem használtak a fiatalok, többségük nem is tudja, mi van a készülékén, mert meg sem nézi. Ilyen sosem használt alkalmazás például az Egészségalkalmazás, a Tippek, a Fotómontázs, a Wallpapers, a Könyvolvasás, a Play Újságok, Play Könyvek, a Google Filmnézés (amiért külön kell fizetni, és a kis képernyố miatt nem élvezhetố a film). Megemlítették még a nem használt applikációk között az NFC-t és a ScreenMirroringot, az Árfolyamot, a Részvényeket, az Iránytút, a Hangjegyzeteket, az Újságost, a Fociarénát, a Watchont, a Dropboxot, a DST beállításokat, a Hangtárcsázót, a Hangvezérlést, a Mobilvásárlást, a Telekom - Telekom nekem alkalmazásokat. Miután egyszer beállították maguknak a készüléküket és megszokták abban a formában, nagyon ritkán változtatnak rajta. Ez utóbbi függhet az élethelyzet változásától, például amikor általános iskolásból középiskolások lesznek, egyetemre mennek, esetleg elkezdenek dolgozni.

Alanyaink szerint a telefonjuk adta lehetôségek körülbelül 70 százalékát használják, a többit sajnos nem tudják kitörölni, és ezzel helyet felszabadítani.

A diákok a közösségi oldalakon való állandó jelenlét és zenehallgatás miatt szinte egész nap használják telefonjukat. Próbáltuk megtudni, hogy ez naponta körülbelül hány órát jelent, de nem tudtak rá válaszolni, mert valóban folyamatosan kéznél van a készülék, folyamatosan kommunikálnak egymással.

\section{Elégedettség - jó és rossz élmények}

Az alanyok okostelefonjukkal kapcsolatos elégedettségüket 10 pontból általában és átlagban 8 pontra értékelték. A hiányzó 2 pont a következô okokból ered: gyakran elófordul már egy egy-másfél éves készülékeknél is, hogy egy letöltött videó megáll néhány másodpernél. Ez nagyon bosszantó tud lenni. De említhetjük azt is, hogy a telefont nem mindig 
lehet kedvük szerint bôvíteni. Ma már egyre több képet és videót készítenek a fiatalok nem úgy, mint négy-öt éve -, amelyek egy idô után nem férnek el a telefon tárhelyén. Ennek köszönhetô, hogy egyre inkább a memória nagysága és bơvíthetôsége lesz a legfontosabb szempont egy vásárlásánál. Fejleszteni kellene még az akkumulátorokat is, hiszen a készülékek a mobilinternet használatakor nagyon hamar lemerülnek.

„Ma már, ha választanom kéne egy dizájnosabb telefon és egy csúnyább, de nagyobb memóriás között, akkor a nagyobb memóriást válasstanám. Két-három éve ez még fordítva volt, de ma már muszáj a nagy memória. Sajnos kicsit lemondanék a tetszetósségról, de azért még nézzen ki valahogy."

A telefonhasználók leginkább múszaki okok miatt voltak bosszúsak telefonjukra, például mikor az lefagy, lelassul, vagy nem jelzi a hívásokat. Igaz, jelentéktelennek túnô, gyorsan megoldható problémákról van szó, alanyaink mégis meglepố türelmetlenségról tanúskodtak a felmerülésükkor. Akár pár perc várakozás után idegessé, mérgessé válnak. Félnek, hogy lemaradnak valamilyen fontos dologról vagy hírról, félnek, hogy kimaradnak valamiból.

„Tegnap vágtam éppen a földhöz, de nem tört el, mert nem jelezte anya hivását, pedig akkor nagyon fontos lett volna. Visszahivásra meg hülyeségeket mondott a telefon, hogy nem elérhetö az illetố, pedig az volt, tudom, mert anya is keresett, találkozót beszéltünk meg, ott járt a környéken, és nem talált engem, mert a helyet telefonon akartuk pontosítani. Mikor végre beszéltünk, akkor meg szakadozott a beszélgetés, csak néhány szót lehetett hallani, és magától lerakta a telefon a kagylót. Újbóli hívásra nincs térerót írt ki a telefon, pedig volt. Újrainditottam, megint nem értem el anyut. Várni kellett egy kicsit, ismét újrahivás, és akkor már jó volt, tudtunk beszélni. Ezeket máskor is csinálta már, ilyenkor újra kell inditani, és rendbe jön minden, de még egy éves sincs a késziilék! És persze pont akkor csinálja ezeket, amikor tényleg fontos, hogy azonnal elérjenek. Húúu... nagyon ideges voltam, kiabáltam a telefonommal. ...Állítólag ki kellene kapcsolni idónként, de nekem éjjelnappal be van kapcsolva. Másik, mikor nem írja ki rögtön, hogy irt valaki. Az üzenet megvan, de nem jelzi, hogy irt valaki a Messengeren. Na, az még komoly."

„Mikor meg voltam hekkelve, és az egy-két ilyen buggal jár, például amikor fényképeznék, akkor ast írja ki, hogy a kamera nem elérhetó. És olyankor a telefont újra kell indítani. Vagy amikor annyira felforrósodik az egész telefon és annyira belassul, lefagy, kidob a Snapchatból... akkor kikapcsolom, újraindítom, nem nyúlok hozzá vagy öt percig, a telefon is meggyógyul addigra, és én is megnyugszom, és akkor utána hoz:áérek. Múltkor beraktam a hütóbe, annyira felmelegedett."

Egyik alanyunk említette, hogy telefonja néha 15, sốt akár 30 százalékos töltöttségi szinten is kikapcsol, azt jelezve, hogy lemerült. Mivel egy három éves telefonról beszélünk, tulajdonosa meg sem lepôdik ezen, érthetố és elfogadott jelenségnek tartja.

Meglepetésról, örömról kevesebb alanyunk tudott beszámolni készülékével kapcsolatban. A többség tudja, mit várhat telefonjától, tudja, mit tud és mit nem tud, így meglepetés sem éri óket. Néhány kivételt mégis leírnánk. Alanyunk - 19 éves, idén érettségizett fiú, szeptemberben kezdte az egyetemet, húséges iPhone használó, jelenleg iPhone5-öt használ - most fedezte fel, hogy a telefonján van órarend, amelyet szerkeszthet egy naptáron keresztül. Ugyan így bukkant rá a „ne zavarjanak” funkcióra is. Egy 16 éves lány véletlenül fedezte fel, hogy nemcsak fotókat, hanem filmet is tud venni:

„...például mikor rájöttem, hogyha folyamatosan nyomom a fotózás gombot, úgy gyorsan, akkor másodpercenként vesz a kamera, olyan mintha film lenne. De én est nem tudtam, véletlenül derült ki, mikor hirtelen 25 kép lett a telefonomban, mondom, mi az Isten ez, honnan van basszus, és megnéatem, és akkor jöttem rá, mi történt. De tök jó, úgy meglepódtem, úgyhogy már ezt is tudom." 
Egy másik 16 éves lány egy házibulin tudta meg, hogy telefonján van GroupPlay alkalmazás, melyet azóta társaságban rendszeresen használnak.

Kíváncsiak voltunk és megkérdeztük alanyainkat, mire lenne még szükségük telefonjukban, mi az, amit hiányolnak. Legtöbbjük elégedett telefonjával, egyes alanyok azonban örültek volna a szemkövetó funkciónak, ami már megtalálható egyes típusoknál (ha a telefon érzékeli, hogy nem nézik, akkor magától kikapcsol) vagy az automatikus fényerôsség-szabályozónak. Hiányzott nekik a digitális szkennelés is, amely fényképezés hatására digitális szöveggé alakít egy szöveget, bár ennek létezésében nem voltak biztosak. Az egyik 18 éves fiú örülne, ha kivetíthetné a Skype-ot vagy a térbe vagy a falra. Úgy tudja, az ezzel kapcsolatos terveken dolgoznak- látott már ilyen kamerát. Egy hangfelismerô funkció is tetszene egyiküknek, amely ha mond valamit a telefonba, az elhangzottakat szöveggé alakítja. Létezik már ilyen készülék, de az övében nincs rá lehetôség. Jegyzetkészítésnél, csetelésnél használná.

\section{ÉNés a telefon}

Kutatásunk elején volt egy hipotézisünk, mely szerint a tizenéves korosztálynak fontos a telefon külseje, megjelenése, hiszen ez identitásuk, személyiségük kifejezésének egyik eszköze. Ebben a korcsoportban a külsôségek, a megjelenés nagyon fontos tényezô. Azonban azt tapasztaltuk, hogy ez nem minden esetbe van így, illetve ha így is van, a külsóre kisebb hangsúly kerül, mint a telefon többi tulajdonságára. 10 interjúalanyunk közül csupán 2 lány (egy 16 éves és egy 17 éves) mondta azt, hogy nem különösebben érdekli, mi van a telefonban, ók pusztán a telefon megjelenése alapján választanak. Ha több készülék is tetszik nekik, akkor a memória nagysága,a gyorsaság, a kamera minósége - ,ami minden embernek fontos"-szerint döntenek.

A védôtoknak az a szerepe, hogy védje a telefont a sérüléstốl, a tok kiválasztásánál ezért ez az elsôdleges szempont. A továbbiakban fontos lehet a színe, mintája és megjelenése is. A többségnél (2 megkérdezett kivételével) ez azonban nem fontos. Sót, az iPhone-t szeretốk és használók kimondottan nem szeretik a tokokat, mert az eltakarja az iPhone szépségét. De mégis muszáj használni, hiszen elófordulhat, hogy kicsúszik a zsebból vagy leejtik.

Alanyaink szerint a telefon kinyitása után, az ikonok megjelenésekor, egyeseknél már a héttérkép alapján megállapítható, kié a telefon. A rajta található alkalmazások, azok elhelyezése, az állomány és tartalom rendszerezése is árulkodó. Ha még a letöltött zenékbe is belehallgatnak, akkor pedig már semmi kétségük a felól, ki használja az adott telefont. A kis LED-kijelzố különbözó színekkel és villogásokkal jelzi az üzeneteket. Ezt is lehet személyre szabni, a színeken és a villanásokon változtatni. Van olyan alkalmazás, amellyel az ikonokat lehet megváltoztatni (például a színeit, így egy Facebook-logó nem világoskékfehér lesz, hanem „csajosabb”, rózsaszín), ezzel még egyedibbé válhat a megjelenés, ahogy a különbözó betútípusok megváltoztatásával is.

„Én tettem olyan telefonná, amilyen én vagyok. Ez én vagyok. Eleinte nem az volt, de most már igen. Ez nekem fontos, mert használom, úgy érzem, én vagyok, a részem, és úgy is bánok vele." 


\section{Az okostelefon mellett más infokommunikációs eszközök}

A kutatás során megkérdezett diákok egyike sem csupán okostelefonnal rendelkezett az infokommunikációs eszközök közül, hanem mindenkinek volt más készüléke is. Legtöbbször laptop vagy tablet, néhányuknál asztali számítógép. A számítógépet általában a család használja, mindenkié, de idônként játékra vagy házi feladat megírására is igénybe veszik. Egybehangzó tapasztalat azonban, hogy amióta okostelefonnal rendelkeznek, sokkal kevesebbet használják, mint elótte.

Interjúalanyaink mindegyike arról számolt be, hogy a filmeket tableten vagy laptopon nézik, így kényelmesebb, ráadásul a telefonon ezek túl sok helyet foglalnak el.

Kevesen használják a Skype-ot, de akik igen, azok mindennap, akár több órán keresztül is, szintén tableten vagy laptopon.

A beadandó házi feladatokat is ezeken írják, például a PPT-fájlokat csak ezeken lehet jól szerkeszteni és kezelni. Ha több forrásból kell esszét írniuk, akkor a keresés vagy egyszerre több ablak megnyitása csak nagy képernyốn lehetséges. A nagyobb fordításokat is ezeken végzik, igaz, egy-két szó kikeresése telefonon is történhet. A nagyobb képernyoón kényelmesebb és jobban látható a feladat. A szakközépiskolások szakmai képzéséhez szükséges programokat is csak laptopon tudják használni, ilyen például egy AutoCAD nevú tervezóprogram. Alanyunk szerint a képernyố és a billentyúzet miatt csak azon lehet tervezni, a kép jobban átlátható és módosítható, de a tervet a mobilon magával tudja vinni, és úgy használni munka közben. A telefon képernyôjén ez a program túl kicsi méretben jelenik meg.

Többen a zenék letöltését is laptopon végzik, onnan teszik fel azokat a telefonjukra.

A videók vágása, szerkesztése, fotók nézegetése is laptopon vagy tableten történik.

A fentieken kívül rendszeresen játszanak is a tableten, a laptopon vagy az asztali számítógépen. A játékok közül a nagyobb hely- és gépigényúekkel, például FIFA, Call of Duty, Sims, League of legends. A laptop és a tablet vásárlásánál az is fontos szempont, hogy lehessen rajtuk játszani.

\section{Aszïlói kontroll}

A szülók elvárásai gyerekeik telefonját illetốen csupán az, hogy gyerekeik mindig elérhetốek legyenek, a gyerekek is mindig értesíteni tudják szüleiket, vagyis biztonságban tudják óket. Ha erre alkalmas egy telefon, akkor megveszik. Ha ennél több kell a gyereknek, akkor hajlandóak kompromisszumokat kötni.

A szülók - a megkérdezett alanyok többségénél - nem szólnak bele, milyen telefont vásárol, illetve használ gyerekük. A 10 megkérdezettból mindössze 1 apuka tájékozódik és olvas hosszabban a telefonok tulajdonságairól, hogy a fiával együtt válasszák ki a készüléket. A szülók többsége nem ért az eszközökhöz, nem érti mitól jobb, rosszabb vagy más az egyik telefon, mint a másik, inkább gyerekére bízza a választást, mert az egyrészt jobban ért hozzá, másrészt ô tudja, mire akarja használni.

A szülók kivétel nélkül beleszólnak azonban az árba. A korábban említett apukán kívül még 2-3 apuka van, aki valamennyit ért a mai telefonokhoz, és lehet vele egyezkedni, de az árak ott is kötöttek. A szülók megmondják, mennyi pénzt hajlandóak a készülékért 
és a fenntartásért adni. Ha az adott keretnél többe kerül egy készülék, akkor a gyerekek kipótolják az összeget a zsebpénzükból, nyári munkákból, ajándékba kapott pénzekból. Egy új okostelefon vásárlására átlagban ötven-hetvenezer forintot hajlandóak kifizetni, de a „megrögzött” iPhone használók tudják, hogy minimum százezer forint fölé kell menniük, amit a gyereknek még ki kell egészítenie. Ha a gyereknek valóban olyan fontos egy telefon, a szülók elvárják, hogy a kereten felüli összeget ók maguk spórolják össze, munkavállalással és/vagy a szabadidejük feláldozásával. Kutatásunk azt bizonyítja, hogy a gyerekek valóban hajlandóak áldozni kedvenc telefonjukra.

A közösségi oldalakra a szülók ritkán mennek fel. Néhány alanyunk elmondta, hogy egyik szülóje fenn van a Facebookon és egy csoportban van vele, de nem zavarják egymást. A gyerekek nem viselkednek másként, ha a látják óket szüleik. Persze elófordultak olyan esetek, amikor a szüló a csoportban kommentelte fia véleményét (ahogy ók fogalmaztak, „próbált jó fej lenni”), a többiek ezt tolerálják, még ha ez arra is sarkallja óket, hogy szüleiket figyelmeztessék egy hasonló helyzet elkerülésére. Komoly véleménykülönbségek, összetúzések még nem voltak az együttes „fennlevésból”. Az más eset, amikor valamelyik tanáruk vagy osztályfőnökük is tagja közös csoportjuknak. Akkor muszáj másképp viselkedni, vigyázni kell, mit mondanak, és milyen képeket tesznek fel.

Titkok, rejtegetnivalók nincsenek a telefonokon, esetleg néhány intim fénykép barátnókró́l és barátokról, PIN kódok, de ezeket rendszerint átteszik a laptopjukra vagy tabletjükre, hiszen sok helyet foglalnak, és abban az esetben, ha a telefon elveszik/elromlik, a fénykép megmarad. Sem a szülók, sem társaik, barátaik elól nem titkolnak semmit, bármikor belenézhetnek telefonjukba.

„...nincsen semmi, nem, nem csinálok semmi olyat, amit rejtegetnem vagy titkolnom kéne. A barátaimnak megmutatok mindent, bárki, bármikor elkérheti a telefonom és belenézhet, nincs rajta semmi olyan. Belépési kód, sár van rajta, mert az elózó készülékemen nem volt és gyakran íródtak véletlenül mozgás közben SMS-sek és levelek, a zsebemben, tudod, feloldódott a billentyüzet, de más nincs. A faterom is nyugodtan megnézheti, fel is szokta venni, ha közös ismerós hív. Én nem titkolok semmit, nincs mit, nincs takargatnivalóm."

A szülók tisztelik gyerekeik magánszféráját, megbíznak bennük annyira, hogy tudják, nem tesznek fel magukról kompromittáló képeket az internetre, és nem írnak felelótlen, fel nem vállalható kommenteket, szövegeket. Emellett persze a fiatalok is tisztában vannak a veszélyekkel.

\section{Élet okostelefon nélkiil}

A leginkább elgondolkodtató kérdés alanyaink szerint az utolsó kérdésünk volt, miszerint el tudják-e képzelni életüket okostelefon nélkül. Kivétel nélkül azt a választ kaptuk, hogy nagyon furcsa lenne, nagyon más világ lenne. Hiszen az a jó az okostelefonban, hogy minden percben kapcsolatban állnak a többiekkel. Ez az oka annak, hogy nagyon hiányozna nekik, - így nem tudnák, mi történik a barátaikkal. Ha nem lenne okostelefon, akkor „sima” mobilon egyesével felhívni óket furcsa és idôígényes, kicsit feszélyezett lenne.

De megoszlanak a vélemények abban, hogy érzelmileg ez hogyan érintené óket. Van, aki teljesen elveszettnek érezné magát, van, aki tudna alkalmazkodni, és van, akinek az élete, a napi ritmusa egyáltalán nem változna, nem lenne nehezebb az élete, csak más. Néhány idézet: 
„Amikor nincs kapcsolat a többiekkel, nagyon stresszesnek éræem magam, mert megszoktam, mert egyszerüen szükségen van arra, hogy beszélgessek velük folyamatosan, és félek, hogy lemaradok dolgokról, hogyha nincs telefonom, fóleg okostelefonom."

„Hát, olyan még sose volt, hogy akár egyetlen napra ne lett volna nálam telefon. Nem is bírnám ki, szerintem. Nekem már belém van ivódva a mozdulat, hogy mindig itt van a bal ssebemben, ahogy jelez, kiveszem, ha nem éræem, ott elkezdek pánikolni, hogy az as:talomon hagytam, vagy hol van... megszokás, szeretem, ha mindig elérhetó vagyok, rossz érzés, hogy nem vagyok elérhetó, ha valami történik vagy engem keresnének, akkor nem tudom felvenni, vagy nem tudok visszaírni valakinek."

„Engem nem zavarna, meglennék nélküle. Akkor délutánonként, suli után odaülnék a laptop elé,és akkortól élném a társas életet. Biætos sietnék haza a suliból, többet lennék otthon, de ha megbeszélünk egy programot, akkor ugyanúgy tudok velük találkozni. Csak akkor tényleg jöjjenek el. Lehet, hogy még több idóm is lenne, mert nem írogatnánk annyit egymásnak."

Ha nem lenne okostelefon, többet találkoznának a barátokkal, esténként inkább beszélgetnének, telefon nyomkodása helyett. Talán többet edzenének, többet tanulnának vagy visszatérnének a játékkonzolhoz. Viszont egyöntetú a vélemény abban, hogy nehezebb lenne megszervezni és összehozni a találkozókat, és ha valamelyiküknek közbejön valami (például késik), akkor lassabban és nehezebben tudná értesíteni a többieket. A spontán találkozások pedig esélytelenek lennének. De a barátokkal való találkozás biztosan nem csökkenne.

„Húúu... az nagyon más lenne minden, mert akkor annyira elóre le kéne mindent fixálnom, és menet közben, ha közbejön valami nem tudok szólni, és pontosnak kell lennem mindenhol, és tényleg akkor napokkal elöre meg kell beszélnem, hogy jó, akkor szerdán kettókor találkozunk, és akkor, ha mit tudom én, nem érek oda, akkor nem tud elérni, vagy ha ö nincs ott, akkor én sem tudom ót, és akkor az igy nekem ... az úgy nagyon...nagyon nehés lenne."

Azonban abban az esetben, amikor számukra izgalmas, érdekes program adódik, képesek félretenni a telefont. Ilyen egy nyaralás, egy sportfoglalkozás, egy jó házibuli vagy épp egy nyári munka. Ha nem unatkoznak, akkor nem hiányzik nekik a jelenlét és a többiektól származó információk.

„Nyaraláskor egy hétig nem volt telefon, mert eveztünk Csehországban és téreró" sem volt, mert hegyek között eveztünk, meg veszélyes volt a ví miatt is, jól elpakoltuk a telefonokat, de jól esett. Nem is hiányzott, jó volt egy kicsit kikapcsolni és pihenni és nem cseszegettek minden hülyeséggel a többiek... ez attól függ, milyen körülmények között vagyok. Most pár hete a hegyekbe meg barlangba mentïnk néhány napra anyáékkal, csak este néstem meg mi van, és nem volt semmi fontos. Ha otthon vagyok és unatkozom, meghalnék nélküle. Ha nyaralunk, akkor simán ki lehet bírni nélküle, nem hiányzik, és nem érdekel. Ha el vagyok foglalva, akkor csak akkor nézem meg, ha jelez a telefon, mert amúgy van mit csinálni."

„Nagyon olyan környezet kéne hozzá, ahol van mit csinálni és teljesen lefoglal. Legutóbb Spanyolországban voltam nyaralni az osztállyal, egy fa bungalóban laktunk, és ott nem hiányzott, mert tí percre volt a tengerpart és a másik oldalon egy medence, egész nap strandoltunk. Ahol van mit csinálni, ott annyira nem fontos. Maximum írok egy SMS-t, ha megérkezek, anyának, de mást nem. Ha mentïnk kajálni, és utána csak megnéztem a telefont, akkor. De ha otthon vagyok és unatkozom, akkor kell... azért ha nem lenne velem nyaralásnál hiányozna, de nem hašnálnám sokat, csak a bistonságérzet miatt kell."

Ha csak átmeneti az okostelefon-nélküliség, akkor azt az idốt gond nélkül, türelemmel átvészelik már meglévố eszközeikkel, így például a telefont kiváltja a korábbi, „vész- 
tartalékba” eltett készülék, a laptop vagy tablet. Akkor ezeken kommunikálnának egymással, és ezeken keresztül hallgatnának zenét. Egy-két kivétellel mindegyik alanyukkal elófordult már, hogy rövidebb-hosszabb idôre nem volt okostelefonja. Alkalmazkodtak a helyzethez, gond nélkül megoldották a problémát.

\section{Összefoglalás}

Legfontosabb kutatási eredményeinket összegezve a következô megállapításokat tehetjük:

- Az elsố okostelefonokat interjúalanyaink négy-öt éve (2011-2012-ben) kapták, illetve szüleiktól kérték. Akkor általános iskolás hetedik-nyolcadik osztályosok voltak.

- Az elsố okostelefonról még nem tudták mire való, elsôsorban játékra, barátokkal való kommunikációra, valamint zenehallgatásra használták. Akkor még nem volt szempont, hogy mobilinternetük is legyen.

- Az elsố telefonok múködését a diákok jelentôs többsége egymaga tanulta meg kezelni, illetve barátaikkal, osztálytársaikkal együtt fedezték fel, mit és hogyan kell rajta használni. Csak azokat az alkalmazásokat használták, amiket korábban is, vagy amiket a többiek is.

- Alanyaink jelenleg a harmadik-ötödik telefonjukat használják, és ez négy-öt éves idôtartamot fed le.

- A telefonok lecserélése szinte minden esetben egy-másfél, maximum kétévente történik, és nem elsôsorban elromlás vagy használhatatlanná válás miatt, hanem mert vonzódnak az újhoz, valamint mivel a korosztályuk körében mindenki két éven belül cseréli le, ez tovább gerjeszti az elvárást, hogy ốk is lecseréljék. Szerintük a mai készülékeket eleve két-három évre tervezik, hogy utána újat kelljen venni.

- Minden megkérdezett diáknál a belassulás, a lefagyás volt az oka a telefoncserének, és többen említették a hirtelen magától kikapcsolást vagy bekapcsolást, a nehéz és többszöri próbálkozásra újrakapcsolást. Az elsődleges szempont egy telefoncserénél a gyors és állandó jelenlét biztosítása, valamint a gyors/azonnali továbbítás lehetôsége.

- Ma már nélkülözhetetlen a mobilinternet. Erre az állandó jelenlét, a folyamatos kommunikáció miatt van szükség.

- Új telefon vásárlásánál szempont a teljesítmény és a termék tetszetốssége is. A szempontok sorrendje változó. A diákok tudatosan vásárolnak, mérlegelnek, hogy mire használnák a készüléket, ehhez képest rangsorolják elvárásaikat is. Barátoktól, ismerôsöktól és az internetról szerzik információikat a készülékekról.

- Az okostelefon-használatnál mindenkinél kivétel nélkül az állandó kommunikáció, a „fennlevés” az elsốdleges szempont. Mindegyik megkérdezett használja a Facebookot, Messengert, Snapchatet, Instagramot, WhatsAppot, Vibert, és zenét hallgat. Ezeket napi szinten, állandó jelleggel.

- Fotózásra, videók nézésére, böngészésre, hírek olvasására ritkábban használják, telefonálni és SMS-t küldeni csak alkalmanként szoktak. Amit lehet, ingyenes wifivel próbálnak elérni, de ha az nincs, akkor mindig rendelkezésre áll a mobilinternet.

- Számos olyan alkalmazás van egy telefonon, amit sosem használtak, többségük nem is tudja, mi van a készülékén, mert meg sem nézi. Ha egyszer beállították maguknak készüléküket és megszokták, akkor nagyon ritkán változtatnak rajta. 
- Telefonmárkát ritkán váltanak, a már megszokottat szeretik.

- Az okostelefonnal kapcsolatos elégedettséget vizsgálva arra jutottunk, hogy a diákok 10 pontból 8 pontot adnak készüléküknek. A hiányzó 2 pont a múszaki, javítandó paraméterekre utal. Összességében elégedettek a telefonjukkal, vigyáznak rá kívül és belül egyaránt.

- A fiataloknak fontos, hogy telefonjuk tükrözze személyiségüket.

- A megkérdezett diákok egyike sem csupán okostelefonnal rendelkezik, hanem mindenkinek van laptopja vagy tablete vagy asztali számítógépe. Ezeket filmnézésre, Skype-olásra, házi feladatok megírására, zenék letöltésére, játékra, videók és fotók szerkesztésére használják.

- A szülók elvárása: kölcsönös elérhetôség, biztonságérzet. Nem szólnak bele, milyen telefont vásárol, illetve használ gyerekük, csak az árat limitálják.

- Ha nem lenne okostelefon, akkor nagyon más világ lenne. Sokkal nehezebb lenne megszervezni és összehozni a találkozókat, nehezebben tudnák értesíteni egymást a változásokról. Okostelefon híján talán többet találkoznának, többet tanulnának, játszanának vagy sportolnának. Ha nem unatkoznak, akkor most sem hiányzik nekik a jelenlét és a többiekkel való állandó kommunikáció. 